\title{
ФОРМУВАННЯ ПРОФЕСІЙНО ОРІЕНТОВАНОГО ІНШОМОВНОГО НАВЧАЛЬНОГО СЕРЕДОВИЩА ШЛЯХОМ РОБОТИ 3 ХУДОЖНІМ ТЕКСТОМ ЯК РЕАЛІЗАЦІЯ ВИХОВНОГО ПРИНЦИПУ НАВЧАННЯ IНОЗЕМНОЇ МОВИ В УМОВАХ УНІВЕРСИТЕТУ
}

Петько Л. В. Формування професійно орієнтованого іншомовного навчального середовища шляхом роботи 3 художнім текстом як реалізація виховного принципу навчання іноземної мови в умовах університету.

Описано виховання гуманістичних цінностей у студентів ВН3 в умовах професійно орієнтованого іншомовного навчального середовища на прикладі роботи 3 художнім текстом, що стимулює виховання християнських цінностей у студентської молоді. Автор надає зразки вправ до роботи з текстом.

Ключові слова: студенти, університет, професійно орієнтоване іншомовне навчальне середовище, виховання, художній текст.

Петько Л. В. Формирование профессионально ориентированной иноязычной среды обучения путём работы с художественным текстом как реализация воспитательного принципа обучения иностранному языку в условиях университета.

Описано воспитание гуманистических ценностей у студентов университетов в условиях профессионально ориентированной иноязычной среды обучения на примере работы с художественным текстом, что направлено на воспитание христианских ценностей у студенческой молодёжи. Автор предлагает образцы упражнений к работе над литературным текстом.

Ключевые слова: студенты, университет, профессионально ориентированная иноязычная среда обучения, воспитание, художественный текст.

Pet'ko L. V. Formation of the professionally oriented foreign educational environment in the way of working at a literary text as realization of education principle of foreign language learning in the conditions of university.

The author describes education of humanistic values for the students of universities in the conditions of the professionally oriented foreign language educational environment on the example of work at literary text that provides education of Christian values for students. A complex of exercises for work at original literary text by profession aimed at reading skills formation (pre-text exercises), and the formation of reading skills (post-text exercises) for students of universities are developed.

Key words: students, university, professionally oriented foreign language learning environment, education, a literary text.

Уважають, що інтеграційним показником сформованості гуманістичних ціннісних орієнтацій є спрямованість студентської молоді, що виявляється через стійкі мотиви діяльності, інтерес до певних видів діяльності, які соціально значущі, через ставлення до навколишнього світу та оточуючих людей. Виокремлюють три головні види спрямованості: «на себе» (бути здоровим, жити весело, розважатися), «на об’єкт» (наявність цікавої справи, захопленість заняттям) та «на інших людей» (наявність друзів. бажання прийти на допомогу тим, хто поруч). Вивчаючи сформованість гуманістичних ціннісних орієнтацій студентської молоді, Я. Кулікова дійшла висновку, що рівень сформованості останніх у більшості респондентів- 
студентів є недостатнім. Переважно, вони спрямовані «на себе» і представлені сферою найближчого оточення або обмежуються власними інтересами, де «переважають егоїстичні мотиви, індивідуалізм, відсутнє прагнення до досконалості, творчого зростання, внутрішнього культурного розвитку, слабко виражений альтруїзм і практично не простежується етичне переживання глобальних проблем людства [3, с. 262263]».

У свою чергу процес формування гуманістичних цінностей особистості студента науковці розглядають як науково обгрунтовану систему організації і стимулювання активної діяльності студентів, що базується на таких педагогічних умовах, які забезпечують розвиток усіх компонентів гуманістичних цінностей: когнітивного (уявлення й судження особистості про гуманістичні цінності, знання норм гуманної поведінки у взаємодії з іншими, 3 природою), емоційно-мотиваційного (гуманні почуття, емоції, здатність до співчуття, мотиви і цілі, які лежать в основі дій і вчинків людини), поведінкового (уміння співпереживати, гуманні вчинки, готовність робити гуманний вибір в умовах життєдіяльності, ціннісне ставленням до себе, інших, природи) [8, с. 7].

Тому сформоване професійно орієнтоване іншомовне навчальне середовище (ПОІНС) шляхом роботи 3 автентичними текстами класиків літератури (іноземною мовою, яка вивчається), де акцент робиться на виховному аспекті твору, сприятиме професійному й особистісному зростанню студентів, а також становитиме ефективний засіб навчання.

Під гуманістичними цінностями розуміють цінності, «які реалізуються 6 діяльності й спілкуванні особистості заради інших» [8 с. 7]. 3 позицій гуманістичної етики людина щаслива тільки у взаємодії з іншими. У неї $є$ лише один спосіб бути у єдності зі світом і в злагоді із собою - реалізувати свої здібності. Це і зробив старий невдаха, художник Берман у кінці новели «Останній листок» О. Генрі, - намалював на стіні листочок плюща - символ життя, що став справжнім шедевром людських стосунків, в який була вкладена любов до людини, віра в її сили, бажання добра.

Зупинимося більш детально над роботою 3 текстом новели О. Генрі «Останній листок» [9], акцентуючи увагу на реалізацію виховного принципу навчання іноземної мови, що допоможе вивчити «особливості поведінки людини в окремих життєвих ситуаціях, що вимагають морального вибору, і опори на християнські цінності в ситуації вибору $[1$, с. 30$] »$, коли ідея самовизначення, постійного особистісного вибору (вибір життєвого шляху - трудового, сімейного; вибір лінії моральної або аморальної поведінки) і відповідальності за зроблений вибір дуже актуальна серед молоді.

Л. Кожедуб зазначає, що робота з художнім текстом передбачає чотири основні етапи: вступний спонукально-мотиваційний етап, операційно-пізнавальний, контрольно-оціночний, етап творчого переосмислення ХТ (сприяє більш глибокому проникненню в ідейний зміст ХT) [2, с. 31]. Це зумовлює виконання різних типів вправ на кожному етапі.

\section{Лінвістичний коментар:}

1) a short story focuses on one incident; has a single plot, a single setting, a small number of characters; and covers a short period of time;

2) Greenwich Village (pronounced «grennitch») - a small part of New York;

3) irregular: ... the narrow, irregular streets have run crazy and broken themselves into short strips called places; crooked, uneven;

4) quaint: ... quaint, continental atmosphere ...; charming, unique, unusual;

5) epidemic: ... an epidemic forced people from the city ...; an out of control outbreak 
of disease;

6) clusters: ... we find clusters of colorful restaurants, theaters, and shops; groups, bunches, a collection;

7) gables: ... hunting for north windows and 18th century gables and Dutch attics and low rents; the upper part of the end of a house formed by a ridged roof;

8) scoffed: ... scoffed at softness in anyone ...; mocked, ridiculed, scorned;

9) economics: ... their economics of shared rent so demanding, that a joint studio resulted; careful use of money;

10) pneumonia: ... whom the doctors called Pneumonia, ...; a disease characterized by inflammation of the lungs;

11) ravager: ... this ravager strode boldly, swiftly, smiting his victims by scores, ...; one who ruins, wrecks, spoils;

12) zephyrs: ... blood thinned by California Zephyrs ...; warm winds;

13) smote: But Johnsy he smote; ... hit, smack, clobber;

14) curative: ... the curative powers of medicine; to cure as from a disease;

15) dreary: There was only a bare, dreary yard to be seen, and the blank side of the brick house forty feet away; bleak, cheerless, gloomy, dismal;

16) persistent: A cold persistent rain was falling mingled with snow; regular, steady, constant;

17) sill: Sue pulled Johnsy's shade down to the window sill. ..; the bottom of the window;

18) eaves: ... the rain still beat against the windows and pattered down from the low dutch eaves; the overhang of a roof;

19) port: You can bring me a little broth now, and some milk with a little port in it ...; a sweet red wine usually fortified with alcohol [12].

20) satyr ['sætə]: from Latin satyrus, from Greek satyros, of unknown origin. A creature in classical mythology who was part man and part goat. One of a class of sylvan deities, represented as goatlike men who drank and danced in the train of Dionysus and chased the nymphs [11].

21) Michelangelo [mikelandzelo] was an Italian sculptor, painter, architect, poet, and engineer of the High Renaissance.

22) Moses (1393-1273 BCE) was an important prophet in Christanity and Islam.

23) Michaelangelo's Moses beard: Michelangelo himself thought this statue of Moses was among his best works - and many viewers agree. Vasari, the contemporary artist and biographer of Michelangelo said of this statue of Moses «.....Moses may now be called the friend of God more than ever, since God has permitted his body to be prepared for the resurrection before the others by the hand of Michelangelo.» Indeed, Michelangelo's skill as a sculptor can be seen throughout the work. The fabric in Moses' clothes is full of deep folds and at stress points clinging to the man's legs. On his arms you can see the veins and tendons of the hands as he holds the heavy stone tablets, cut square as was custom at the time, before the now common image of the tablets with arched tops. His beard is made up of long flowing hairs full of curls and carved with such detail that individual strains are almost seen.

Moses' face is especially full of detail and emotion. Even though much of the face is covered by the beard, the structure of the face is still defined by heavy cheekbones visible through the tight skin. Having been talked to by God and given the responsibility to present His commandments, Moses is full of thought. His brows furled and eyes looking far beyond. A result of the ever changing nature of this project, some of Moses' features appear distorted. Originally, he was meant to be much higher and viewed from below. In order to compensate for the viewing angle, his torso and head are made larger [10].

Фонетичні вправи. Відпрацювати вимову звука [f] у словах leaf, fragile, herself, 
float, foolishness, off, from, fall, if, friendship, afternoon.

Звернути увагу на правильну вимову буквосполучення -ur [ə:]: curves. До того ж, у звязку 3 тим, що в англійській мові не має місце відповідність між вимовою та написанням для більшості слів, пропонується опрацювання слів за наведеною транскрипцією 3 метою підвищення якості лексичних навичок студентів: curative [ 'kjuərətiv] - цілющий; zephyrs ['zefə] - західний вітерець; quaint [kweint] - незвичний, дивний, забавний; dreary ['drIərI] - похмурий, сумовитий, нудний; gable ['geIbl] фронтон, коник даху; ravage [rǽvid3] - спустошення; pneumonia [nju: 'mounjə] руйнування; запалення легенів; persistent [pə’sIstənt] - живучий, стійкий, упертий; eaves [i:vz] - 1) навіс даху, 2) повіки, вії; ivy ['aIvI] - плющ.

Лексичні вправи. У навчанні іноземної мови головним $є$ створення умов для збагачення словарного запасу тих, кого навчаємо. Тому робота 3 текстом виступає однією $з$ таких умов. Текст новели «Останній листок» [9] можна опрацьовувати на практичних заняттях 3 іноземної мови повністю або за частинами залежно від напрямку підготовки студентів та рівня володіння IM, тоді «разове завдання має бути невеликим, але в результаті таке читання сприяє поглибленню словарного запасу, розвитку розвивальної комбінаторики вживання знайомих слів [4]», до того ж рекомендовано, щоб обсяг одноразового завдання був 8-10 тисяч друкованих знаків, був сюжетно завершеним, зручним для переказу, бесіди, обговорення.

Пропонуємо такі лексичні вправи: 1). Утворіть слова за зразком: the art people artists, painters; a pen - ..., to draw - ... (ink drawing), to count - ..., a masterpiece - ..., mine $-\ldots$. .

2). Знайдіть, зачитайте та перекладіть українською мовою речення $з$ тексту, де $\epsilon$ такі слова: Greenwich Village, quaint, clusters, gables, scoffed, pneumonia, ravager, zephyrs, smote, curative, persistent, sill, eaves, port, satyr, Michaelangelo's Moses beard.

3). Пояснить різницю між словами «шедевр» (masterpiece) та «картиною» (picture) (Explain the difference between a masterpiece and a picture).

4). Знайдіть речення у тексті, де вживається слово last (останній). Утворіть речення з цим словом.

5). Надайте Вашу інтерпретацію таких речень із тексту (Give an extended interpretaition to the following sentences): a) In a little district west of Washington Square the streets have run crazy and broken themselves into small strips called "places.» These "places» make strange angles and curves, b) In November a cold, unseen stranger, whom the doctors called Pneumonia, stalked about the colony, touching one here and there with his icy fingers, c) Mr. Pneumonia was not what you would call a chivalric old gentleman, d) A mite of a little woman with blood thinned by California zephyrs was hardly fair game for the red-fisted, short breathed old duffer, e) When the last one falls I must go, too.

6. Підберіть синоніми до слів (Give synonims to these words): unsuccessful artist, a painter, a failure in art, a fancy, the beating rain, fierce gusts of wind, a dreadful night, a studio, a magazine story, a goosey, a new building, to finish, a satyr, an imp, ill, away, the beating rain, masterpiece.

Усномовленсві вправи: 1) Reproduce in pairs the conversation between Sue and: a doctor, Behrman, Johnsy, 2) Retell the whole story: in brief or in broader lines, 3) Describe the appearance of Behrman, 4) Give an extended explanation to the following phrases: "Leaves. On the ivy vine», "Behrman was a failure in art», "...it's Behrman's masterpiece».

У процесі навчання студентів читацької культури науковці пропонують як освітні технології такі види творів про прочитане: анотація (коротка передача змісту книги або оповідання), відгук (вільний виклад вражень читача про прочитане), есе (невеликий за обсягом роздум або опис окремих компонентів тексту у вільній формі), рекомендація 
(виділення переваг книги або твору 3 метою презентації їх іншим читачам), інтерпретація (власне творче тлумачення тексту, пояснення, розкриття його сенсу) рецензія (критичний розбір прочитаної книги або твору, оцінка компонентів), літературознавчий аналіз (вивчення компонентів змісту і форми твору в єдності 3 використанням термінів і понять науки про літературу), реферат [7, с. 163]. Це налаштовує студентів на вивчення біографії автора, знання його творчості, стимулює до самостійного формулювання своїх думок і почуттів, проблемних міркувань та порівнянь, що викликано твором, а також висловлення свого ставлення до прочитаного.

Наведемо приклад стислого викладу Summary, Resume) новели «Осінній листок»:

\section{Summary}

In May of 1899, in a small Greenwich Village restaurant, Sue and Johnsy met. They become friends and rent an apartment together to share expenses. In November, Johnsy becomes ill with pneumonia. Her illness lingers. She becomes frail and loses hope of recovering. Outside her window is an old ivy vine on which only a few leaves remain.

Johnsy has become so disheartened that she refuses to fight her way back to health and convinces herself that when the last leaf falls off the vine, she will die.

It is the day of «house calls» for doctors, and the doctor tells Sue that if Johnsy is to get well, she must get her mind on something other than her sickness. Sue is worried; she goes downstairs and reveals her fears to Mr. Behrman, a grizzled, unsuccessful artist who dreams of one day painting a masterpiece. Only one leaf remains on the vine now, and even $\mathrm{Mr}$. Behrman is worried that tonight it will fall victim to the wind and rain.

The next morning, when Sue and Johnsy look out the window, the last leaf is still there. Johnsy thinks about her situation and convinces herself that fate caused the leaf to stay on the vine so that she would not die. With this change in attitude, Johnsy gradually gets well. The doctor comes and verifies Johnsy"is recovery. The doctor also tells Sue that Mr. Behrman has pneumonia and is beyond help. He dies that same day.

Later that day, Sue discovers how Mr. Behrman became ill. She tells Johnsy that on the stormy night when the last leaf was about to fall, Mr. Behrman took a ladder, climbed the wall, and painted a true masterpiece - a picture of the last leaf on the brick wall [12].

Пропонуємо таку тематику проектів, рефератів та творів англійською мовою за новелою «The Last Leaf»: «O. Генрі - великий гуманіст сучасності», «Останній листок» О. Генрі - одна з найкращих і найвідоміших новел нью-йоркського циклу», «Гуманізм твору О.Генрі «Останній листок», «Звеличення духовних цінностей у новелі «Останній листок» О.Генрі», «Тема людської великодушності у новелі «Останній листок» О.Генрі», «Чудернацький Грінвіч Віллідж. Богема Нью Йорка», «Зворушлива історія самовідданої дружби і самопожертви у новелі «Останній листок», «Чи в кожному 3 нас- художник Берман?», «Символізм у новелі «Останній листок», «Надайте психологічну характеристику Джонсі», «Надайте психологічну характеристику Бермана», «Надайте психологічну оцінку вадам Бермана», «Опишіть психологічний стан Джонсі», «Обгрунтуйте авторське порівняння художника Бермана 3 пророком Мойсеєм», «Скульптура Мікеланджело «Мойсей», «Що спонукало Бермана вчините саме так?», «Що відкрив мені О. Генрі в новелі «Останній листок»?, «Моє розуміння тези «Поспішайте роботи добро», «Треба прагнути бути людиною, незважаючи на всю жорстокість навколишнього світу, і це можливо» (О.Генрі). Доведіть чи спростуйте цю думку, посилаючись на життєві та літературні джерела, «Novel Novella - Short story and Their Definitionts».

Зазначимо, що для майбутніх викладачів української мови та літератури (вони отримують філологічну освіту), рекомендуємо використовувати всю низку творів, 
описаних вище, тоді як для інших студентів твори та реферати іноземною мовою обираються вибірково, і головний акцент ставиться на виховний аспект у процесі роботи з текстом «Останній листок» О.Генрі.

Серед описаних нами шляхів формування ПОІНС в умовах університету у процесі роботи 3 текстом «Останній листок» пріоритетним було визначено дидактичний принцип виховного навчання IM, де навчальний процес відбувається у суб'єкт-суб'єктних стосунків і особлива увага спрямована на організацію самостійної діяльності студентів та їхню самоорганізацію. Це сприяє формуванню у молоді таких позитивних якостей, як: здатність до самовдосконалення, активність, самовідданість, толерантність, доброзичливість, товариськість, співпереживання, цінування життя, стимулює почуття самопожертви та відповідальності за іншу людину, позитивні ціннісні орієнтації особистості.

До того ж, маючи універсальний вплив на читача, літературні твори виступають важливим засобом залучення студентів до культури країн, іноземна мова яких вивчається, до світу загальнолюдських морально-етичних та естетичних цінностей. «Мова художніх творів у єдності з художнім образом сприяє розвитку мовленнєвої культури, збагаченню мовних знань студентів [6]».

Отже, сформоване ПОІНС $є$ засобом ефективної реалізації педагогічного потенціалу стимулювання у студентів духовно-моральних цінностей, що «виражається в таких педагогічних ефектах: 1) усвідомленому виборі людиною морально-орієнтованої позиції і ухиленні від морально-дезорієнтованої позиції під час розв'язання життєвих проблем; 2) формуванні критеріїв самооцінки вчинків, які визначаються цінностями, вкоріненими у світоглядній складовій традиційного устрою; 3) розвитку засобів аналізу і рефлексії моральних принципів, на основі яких здійснюється вчинок в ситуації вибору; 4) прийнятті образів людської досконалості, виражених у святості як ідеалі морального спрямування людини $[1$, с. 10]», де під соціально-педагогічними проблемами розуміються такі соціальні проблеми, які розв'язуються педагогічними засобами.

Про вчинок Бермана автор пише в кінці новели: старий німець намалював останній листок плюща на цегляній стіні, який став для хворої Джонсі символом боротьби за життя, що не піддається негоді і не падає на землю, і дівчина почала видужувати. Вона зрозуміла, що була не правою, а іiі бажання померти - це великий гріх. Старий художник під холодним осіннім дощем намалював символ життя, заради життя юної дівчини жертвує своїм, в реальному житті виявив силу, здатну подолати смерть - християнську любов, людяність, турботу, направленість на добро.

У запропонованому нами підході формування ПОІНС у процесі навчання іноземній мові студентів на прикладі роботи з художнім текстом були задіяні такі дидактичні принципи навчання іноземних мов i культур, як: наочність, міцність, свідомість, науковість, активність, виховне навчання, систематичність і послідовність, доступність i посильність, міжпредметна координація, ураховані індивідуальні особливості людини, міжкультурна взаємодія [5, с. 110-114].

У контексті викладеного зазначимо, що робота з художнім текстом як реалізація виховного принципу навчання іноземної мови у професійно орієнтованому іншомовному навчальному середовищі в умовах університету сприяє професійному й особистісному зростанню майбутніх випускників університетів, зокрема педагогів, формуванню світогляду сучасної молоді, іiі особистісного вибору, самовизначення, індивідуальних естетичних смаків та професійної іншомовної підготовки студентів, тоді як сформоване професійно орієнтоване іншомовне навчальне середовище $є$ умовою задля духовного становлення і збагачення особистості. 


\section{Література}

1. Берсенева Т. А. Духовно-нравственные основания традиционного уклада жизни как социально-педагогическая проблема: автореф. дис.. на соискание ученой степени д-ра. пед. наук: 13.00.01 / Тамара Александровна Берсенева. - Курск, 2008. 44 с. 2. Кожедуб Л. Г. Модель навчання читання майбутніх філологів на основі інтерпретації лінгвостилістичних засобів художніх текстів / Л. Г. Кожедуб // Іноземні мови : [наук.-метод. журн.] / засн. Київський лінгвістичний університет і вид-во «Ленвіт»; гол. ред. С. Ю. Ніколаєва. - К. : Вид-во «Ленвіт», - 2009. - № 3. - С. 31-35. 3. Куликова Я. А. Изучение сформированности гуманистических ценностных ориентаций студенческой молодёжи / Я. А. Куликова // Социально-экономические явления и процессы. - 2012. - № 1 (035). - С. 260-263. 4. Мальковский Г. Е. Домашнее чтение на английском языке в неязыковом вузе / Г. Е. Мальковский // Іноземні мови : [наук.метод. журн.] / засн. Київський лінгвістичний університет і вид-во «Ленвіт» ; гол. ред. С. Ю. Ніколаєва. - К. : Вид-во «Ленвіт», - 2005. - № 4. - С. 28-30. 5. Методика навчання іноземних мов і культур: теорія і практика: підручник [для студ. Класичних, педагогічних і лінгвістичних ун-тів] / О. Б. Бігич, Н. Ф. Бориско, Г. Е. Борецька [та ін.] ; за заг. ред. С. Ю. Ніколаєвої. - К. : Ленвіт, 2013. - 590 с. 6. Ніколаєнко О. В. До формування соціокультурних та морально-етичних цінностей у студентів ВНЗ у процесі вивчення іноземної мови / О.В.Ніколаєнко, Т. О. Ушата // Вісник Чернігівського державного педагогічного університету імені Т. Г. Шевченка. - Випуск 62. Серія: педагогічні науки: збірник. - Чернігів : ЧДПУ, 2009. - № 62. - 224 с. [Електронний ресурс]. Режим доступу: http://www.uk.xlibx.com/4istoriya/ 15325-41-visnik -chernigivskogoderzhavnogo-pedagogichnogo-universitetu-vipusk-seriya-pedagogichni-nauki-chernigiv2009-1.php 7. Первова Г. М. Духовно-нравственное воспитание студентов средствами чтения / Г. М. Первова // Социально-экономические явления и процессы, 2014. - № 4 (062). - С. 161-164. 8. Тепла О. М. Формування гуманістичних цінностей у студентів аграрних вищих навчальних закладів у позааудиторній діяльності : автореф. дис. на здобуття наукового ступеня канд. пед. наук: 13.00 .07 / Оксана Миколаївна Тепла. - К. 2008. - 23 c. 9. Henry O. The Last Leaf [Web site].- Access mode : http://www.pages.drexel.edu/ ina22/+270/\$270-texts-last_leaf.html 10. Moses [Web site]. Access mode: http://www.michelangelo-gallery.com/ michelangelo-moses.aspx 11. Satyr / British Dictionary definitions for satyr [Web site].- Access mode :http:/dictionary.reference.com/browse/satyr 12. Specific Teaching Suggestions «The Last Leaf» by O. Henry [Web site]. - Access mode: http://www.balancepublishing. com/ leaf \%20teacher.pdf

УДК $811.161 .2: 373$

Уляна Соловій

\section{ПРОБЛЕМНІ АСПЕКТИ ВИКЛАДАННЯ НАВЧАЛЬНОЇ ДИСЦИПЛІНИ «УКРАЇНСЬКА МОВА (ЗА ПРОФЕСІЙНИМ СПРЯМУВАННЯМ)» У ВИЩИХ МЕДИЧНИХ НАВЧАЛЬНИХ ЗАКЛАДАХ}

Соловій У. В. Проблемні аспекти викладання навчальної дисципліни «Українська мова (за професійним спрямуванням)» у вищих медичних навчальних закладах.

У статті порушено актуальні питання викладання «Української мови (за професійним спрямуванням)» у вищих медичних навчальних закладах як нормативної навчальної дисципліни, аргументується необхідність її вивчення у процесі досягнення високого рівня фахової підготовки та формування комунікативної, професійно 